\title{
Çiğdem Öztürk
}

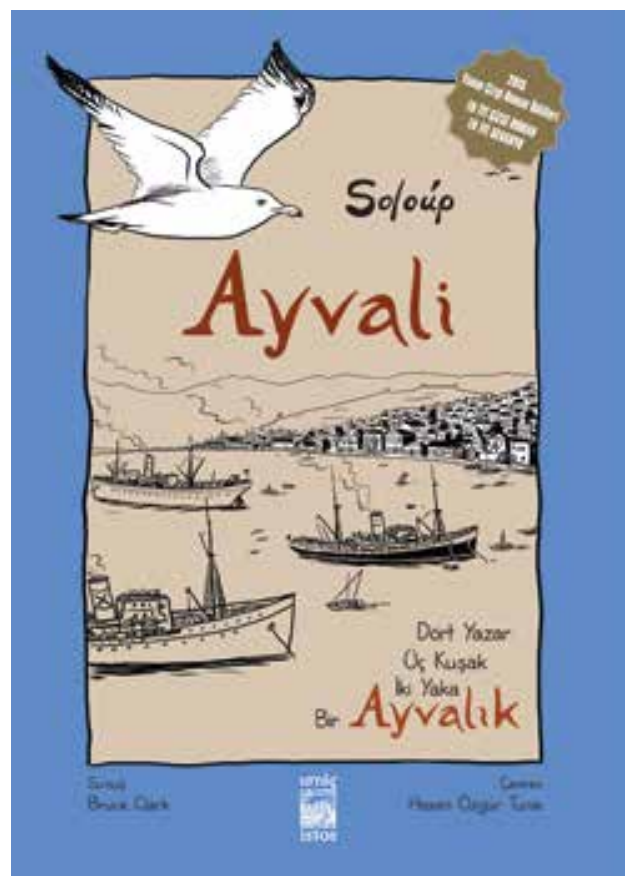

Yunanistanlı çizer Soloúp'un Ege'nin her iki yakasında da büyük ilgiyle karşılanan grafik romanı Ayvali'yi elinize alıp tersten karıştırmaya başlarsanız bir aile albümünün hemen öncesinde "Lozan Antlaşması" başlıklı bir not göreceksiniz. Bir İsviçre kentinde alınan bu kararların en tartışmalısı Yunan ve Türk Halklarının Mübadelesine İlisskin Sözleşme ve Protokol'dür. İmzalanması, "Beş yüz bin Müslümanın Yunan Krall-ğı topraklarındaki (özellikle Girit ve Makedonya'daki) evlerini ve yaklaş̧ı bir buçuk milyon Hıristiyanın, yani Elen'in, eski Osmanlı topraklarını derhal ve ebediyen terk edecekleri anlamına geliyordu."

O ylllardaki toplam dünya nüfusunu dikkate alırsak, bugün dünya üzerinde zorla yerinden edilenlerin sayısıyla kıyaslandığında, akıl almaz bir rakam. Uluslararası hukukun attığı bu düğümü resmi tarih kördüğüm haline getirirken, edebiyat çözmeye gayret ediyor. Bu gayretin son hamlelerinden biri, Soloúp'un İstos Yayınları tarafindan basılan grafik romanı Ayvali: Dört Yazar, Üç Kuşak, İki Yaka, Bir Ayvalık. Ayvali, çizerin Midilli adasına sayısız seyahatinden doğmuş bir hikâye. Aslında bir hikâye demek doğru değil; içine dehşetin, vahşetin, katliamların ve merhametin sığdığı birden çok hikâye. Soloúp Ayvali'yi Ayvalık doğumlu Fotis Kontoğlu'nun Ayvali: Memleketim; İlias Venezis'in Selam Sana, Küçük Asya ve Numero 31328: Amele Taburu kitaplarını; Agapi Venezi-Molivyati'nin anlatısını ve Girit doğumlu Ahmet Yorulmaz'ın Savaşın Çocuklarl ${ }^{2}$ romanındaki hikâyeleri esas alarak çizmiş ve yazmış. Ama arka planda, Bruce Clarke'tan Feride Çiçekoğlu'na, Osmanlı döneminde Ayvalık'a dair en ayrıntılı monografiyi yazan doktor Şerif Mağmumi'den

1 (İstanbul: Belge Yayınlar1, 2015), 264 s., ISBN-13: 9789753446648.

2 2. baskı (İstanbul: Belge Kitabevi, 2002), 135 s., ISBN-13: 9789753441360. 
Kostis Kefalakis'e dev bir külliyat mevcut. Bu süre zarfinda topladığı döneme ait fotoğraflar, belgeler de cabası. Zaten Atina'daki Benaki Müzesi'nde bütün bunlardan müteşekkil bir sergi de hazırlamış. Belki sergiyi bu kıyıya taşımak da nasip olur.

Kökleri İzmir'e uzanan Soloúp, Maral Dink’in Agos'ta kendisiyle yaptığı söyleşide aile hikâyesini şöyle anlatıyor:

Dedem Angelos, Bayındır doğumlu. Küçükken hep duyardım, "Bayindiri” derlerdi Yunancada. Annesini ve babasını küçük yaşta kaybettiği için, onu bir tütün tüccarı olan zengin İzmirli amcası evlatlık edinmiş. Savașın zorlu yıllarında okumak için Berlin'e gitmiş. Büyükannem Maria da İzmir'de doğmuş, babası Fransız demiryollarında terzi olarak çalışıyormuş. Kitapta gördüğünüz fotoğraflar, büyükannem Maria'nın 1919'da Berlin'e, dedeme gönderdiği aşk mektuplarından. Bu yüzden yangından zarar görmemiş, günümüze ulaşabilmişler. Büyükannem de İzmir kordonunda, yangın, deniz ve silahlar arasındaki cehennemde kalan binlerce insan arasındaymış. Çaresizlik içinde, tecavüzden kaçmak ve intihar etmek için denize atlamış. Fakat sonuç olarak, ölü bedenler arasından yüzmüş ve bir Amerikan gemisi tarafından kurtarılmış. Küçüklüğümde, başından geçenleri ayrıntılı bir şekilde anlatırdı bana. ${ }^{3}$

Karşı kıyıda yaşayanların büyük kısmı eski memleketleri Küçük Asya'dan, nam-ı diğer Anadolu'dan benzer hikâyelerle sürülmüş. Devletlerin ve zenginlerin çıkarları çatıştıkça iki halk birbirine zulümde yarışır olmuş.

Ayvali, Soloup'un memleket arama serüveninde Girit'ten sonra Midilli'de karar kılışını anlatan "Zeybebiko" hikâyesiyle açllıyor. Çizer milyonlarca insanın öldüğü savaşların ardından masa başına oturan erkeklerin esaslarını belirlediği modern ulus devletlerin "modernliklerini” askıya aldığı milli kutlamalardan birinin ortasına düşer. Üstelik o esnada adada tatil yapan bir Türk aileye rast gelir, ricaları üzerine arka planda kılıç kalkan benzeri bir mizansenle hatıra fotoğraflarını çeker. Midilli'de askerlik yaptığı yıllarda karşı kıyıya bakıp aklından geçenleri şöyle anlatır: "Bölüğüm ressam Teofilos'un köyündeydi. Her gün karşıda doğunun dağlarını görürdüm. Bunların Türkiye'nin dağları olduğunu düşündügüumde karşımda tehditkâr bir şekilde koskocaman yükselerek beni yemeye hazır dururlardı. Sonra bunları Küçük Asya olarak, Herakleitos'un, dedelerimin dağları olduğunu düşündüğümde hemen ufalıp birer Akdeniz tepesine, verimli tarlalara ve konuksever sahillere dönüşürlerdi.” Böylece Kontoğlu'nun kitabını alıp Ayvalık’a doğru yola koyulur.

Ayvali'nin Kontoğlu'na dayanan "Prelüd” bölümü, Ayvalık'ın ilk çağlarından, bir papazın sadrazamla dostluğu sayesinde elde ettiği

3 Maral Dink, “íki memleketli grafik roman 'Ayvali-Ayvalık', Ege'nin iki yakasını buluşturuyor", Agos, 15 Ocak 2016,

http://www.agos.com.tr/tr/yazi/14,027/iki-memleketli-grafik-roman-ayvali-ayvalikegenin-iki-yakasini-bulusturuyor. 
imtiyazların hükmünü sürdüğü döneme uzanıyor. Ardından gelen "Füg” Ayvalıklı İlias Venezis'in mübadeleden önce, sağ kurtulmanın neredeyse imkânsız olduğu amele taburlarıyla Anadolu'nun içlerindeki çalışma kamplarına yollanmaktan kurtulmak için ailesiyle birlikte verdiği mücadeleyi anlatıyor. İlias Venezis'in bu hikâyeyi anlattığı Numero 31328: Amele Taburu uzun yıllar yasaklı kaldıktan sonra geçen yıl Türkçede de yayımlanmıştı. "Agapi-Zehra”, aynı hikâyeyi İlias Venezis’in kız kardeşi Agapi Molivyatis'in gözünden anlatıyor. Ağabeyini kurtarmak için çabalayan Agapi'ye yardım eden, kendi ailesi karşı tarafın askerleri tarafından öldürülmüş bir Türk subayı. Agapi, tıpatıp subayın öldürülen kız kardeşi Zehra'ya benzediği için subay onun acı çekmesine dayanamıyor. Bir sonraki bölüm "Hasanakis"le Midilli'den çıkıp Girit'e gidiyoruz. Bir zamanlar ahenk içinde yaşanan ama milliyetçilik dalgası vurunca cehenneme dönen adaya. Ahmet Yorulmaz'ın, Giritli Hasan'ın köyünden sürülüşünü, babası öldürüldükten sonra mübadeleye kadar yirmi altı yıl yaşadığı Hanya'daki hayatını anlatan romanına dayanan bölüm aslında barış umuduna dair. Sonuncu bölüm "Köroğlu" çizerin Ayvalık seyahatinde önceki hikâyelerin izlerini arayışını anlatıyor. Cunda'da gezerken karşılaşıp ahbap olduğu, kendisi gibi Lozan'ın torunlarından Mehmet'le muhabbeti "Bizimkiler-Sizinkiler" ikiliğinin sınırlarında geziniyor. Bu sınırları aşıp karşı tarafın acısını tanımak yeni bir tarihin başlangıcı belki de.

Ayvali eski fotoğraflarla sona eriyor. W. G. Sebald bir söyleşide eski fotoğraflar için şöyle der: "Eski fotoğraflarda nostalji hissinden çok, büsbütün gizemli olan bir şey var, âdeta kaybolmak için tasarlanmışlar, sanki tavan arasında ya da sandıkta yitip giden bir albümdeler, kazara gün ışığına çıkıp karşınıza çıkacak gibiler.” Bu fotoğraflarda da Sebald'ın sözünü ettiği gizem yerli yerinde, ancak bu fotoğraflar karşımıza bir taleple çıkıyor. Ayvali'de Soloúp bu talebe cevaben resmi tarihin pusunu, pasını savarak sözü gerçek kahramanlara veriyor. Ayvali bir yanıyla da “yardımcı bir kitap”. Bugün memleketindeki savaştan ve açlıktan kaçarak kimseye görünmeden Ayvalık'la Midilli arasındaki yolu canları pahasına lastik botla alan mültecilerin trajedisini anlamak için de başvurulabilecek bir kaynak.

Soloúp, Ayvali: Dört Yazar, Üç Kuşak, iki Yaka Ayvalık, çev. Hasan Özgür Tuna (İstanbul: İstos Yayıncılık, 2016), 448 s., ISBN-13: 9786054640416. 